\title{
Erratum to "Major gene interactions effect identification on the quality of Hanwoo by radial graph"
}

\author{
Jea-Young Lee · Jae-Young Bae · Jin-Mok Lee · Dong-yep Oh · Seong-Won Lee
}

[해당 논문]

Lee, J. Y., Bae, J. Y., Lee, J. M., Oh, D. Y. and Lee, S. W. (2013). Major gene interactions effect identification on the quality of Hanwoo by radial graph. Journal of the Korean Data $\&$ Information Science Society, 24(1), 151-159.

[수정 내용]

<잘못된 내용>

p.151 네 번째 저자의 소속이 영남대학교 생명공학부로 잘못 표기됨.

p.159 네 번째 저자의 소속이 School of Biotechnology, Yeungnam University로 잘못 표기됨.

<수정된 내용>

p.151 네 번째 저자의 소속을 경상북도 축산기술연구소로 수정함.

p.159 네 번째 저자의 소속을 Gyeongsangbuk-Do Livestock Research Institute로 수정함. 